\title{
KEUNGGULAN KOMPARATIF DAN KOMPETITIF USAHA AGRIBISNIS AYAM RAS PEDAGING DI KABUPATEN LAMONGAN JAWA TIMUR
}

NOVI ITSNA HIDAYATI

Dosen Jurusan Agribisnis, Fakultas Pertanian Universitas Yudharta Pasuruan

ABSTRACT: The aim of research are: (1) Analyze comparative and competitive adventage of the broiler agribusiness industry at the Regenzy of Lamongan, East Java (2) Analyze avian influenza impact regarding to broiler agribusiness industry at the Regenzy of Lamongan, East Java. Research location in selected by purposive sampling method with concideration that the Regency of Lamongan is one of central production which is nearby with main market, Surabaya, and also obviously the one of positively infected. The research result shows the performance of broiler agribusiness industry at the Regency of Lamongan still not really good, based on IP value is 240 or less than 270 financial and economic income of broiler agribusiness industry at the Regency of Lamongan, before and after infected to eny scala of industry has positive value, ir means broiler agribusiness industry made financial profit for breeder and give economic adventage for the people, broiler agribusiness industry at the Regency of Lamongan entirely has comparative and competitive adventage showed by DRCR value less than 1 .

Keywords: comparative, competitive and broiler agribusiness

PENDAHULUAN
Agribisnis perunggasan
nasional telah mengalami
perkembangan yang sangat pesat
sejak dekade 1960-an. Sejak saat itu
usaha budidaya ayam ras, baik ayam
ras pedaging maupun ayam ras
petelur, berkembang menjadi usaha
budidaya berskala rumah tangga.
Saat ini, dunia perunggasan
Indonesia sudah berkembang lebih
pesat, sehingga menjadi industri
perunggasan, terutama pada ayam
ras pedaging (Abidin, 2002).
Pada saat krisis tahun 1998
- 1999, industri ayam benar-benar
terpuruk, produksi ayam ras
pedaging turun dari tumbuh positif

$12,74 \%$ per tahun pada periode tahun 1993 - 1997 menjadi negatif sebesar $28,23 \%$ per tahun pada periode 1998 - 1999. Semuanya itu disebabkan karena biaya ongkos produksi yang melonjak serta turunnya permintaan pasar (Syafa'at, dkk. 2004).

Selama periode $2001-2005$ populasi ayam ras pedaging $\mathrm{di}$ Indonesia dari tahun ke tahun mengalami peningkatan kecuali pada tahun 2003 dan 2004 yang mengalami penurunan sebesar $2,04 \%$ dan $8,84 \%$. Hal ini disebabkan munculnya penyakit Avian Influenza atau flu burung. Perkembangan populasi ayam ras 
menurut propinsi terutama di pulau Jawa pada tahun 2001 - 2005 mengalami perkembangan yang cenderung berfluktuasi. Tahun 2005 saat merebaknya flu burung, Propinsi Jawa Timur merupakan

Tabel 1. Populasi Ayam Ras Pedaging dan Produksi serta Konsumsi Daging Ayam Ras di Beberapa Propinsi di Jawa Tahun 2001 - 2005

\begin{tabular}{|c|c|c|c|c|c|}
\hline Propinsi & 2001 & 2002 & 2003 & 2004 & 2005 \\
\hline $\begin{array}{l}\text { Populasi } \\
\text { (Ekor) } \\
\text { Jabar } \\
\text { Jateng } \\
\text { Yogyakarta } \\
\text { Jatim } \\
\text { Indonesia }\end{array}$ & $\begin{array}{r}238.050 .365 \\
53.879 .259 \\
15.873 .340 \\
\mathbf{3 0 . 2 9 8 . 0 0 0} \\
621.870 .428\end{array}$ & $\begin{array}{r}269.778 .372 \\
97.485 .297 \\
30.582 .672 \\
\mathbf{3 0 . 7 6 3 . 5 6 0} \\
865.074 .785\end{array}$ & $\begin{array}{r}296.160 .072 \\
66.646 .915 \\
16.058 .406 \\
\mathbf{3 0 . 8 5 7 . 4 9 7} \\
847.743 .895\end{array}$ & $\begin{array}{r}328.015 .53 \\
6 \\
50.356 .308 \\
17.325 .991 \\
32.857 .497 \\
770.909 .84 \\
3\end{array}$ & $\begin{array}{l}385.680 .666 \\
50.575 .632 \\
18.192 .290 \\
\mathbf{2 8 . 5 2 0 . 4 8 0} \\
864.246 .136\end{array}$ \\
\hline $\begin{array}{l}\text { Produksi } \\
\text { (ton) } \\
\text { Jabar } \\
\text { Jateng } \\
\text { Yogyakarta } \\
\text { Jatim } \\
\text { Indonesia } \\
\end{array}$ & $\begin{array}{r}163.847 \\
53.661 \\
8.467 \\
\mathbf{8 7 . 0 0 8} \\
536.954\end{array}$ & $\begin{array}{r}216.632 \\
81.676 \\
20.994 \\
\mathbf{1 0 1 . 5 2 0} \\
751.929\end{array}$ & $\begin{array}{r}242.990 \\
66.997 \\
19.115 \\
\mathbf{1 4 2 . 3 3 6} \\
771.112\end{array}$ & $\begin{array}{r}263.397 \\
63.592 \\
18.561 \\
\mathbf{1 6 2 . 7 8 1} \\
846.097\end{array}$ & $\begin{array}{l}263.397 \\
64.140 \\
18.746 \\
\mathbf{1 2 8 . 3 4 2} \\
883.370\end{array}$ \\
\hline $\begin{array}{l}\text { Konsumsi } \\
\text { (ton) } \\
\text { Jabar } \\
\text { Jateng } \\
\text { Yogyakarta } \\
\text { Jatim }\end{array}$ & $\begin{array}{r}199.067 \\
170.532 \\
16.829 \\
227.179\end{array}$ & $\begin{array}{r}247.761 \\
176.658 \\
18.347 \\
248.212\end{array}$ & $\begin{array}{r}271.249 \\
108.103 \\
24.758 \\
\mathbf{3 1 1 . 6 5 7}\end{array}$ & $\begin{array}{r}284.498 \\
109.400 \\
25.006 \\
\mathbf{3 3 3 . 5 1 6}\end{array}$ & \\
\hline
\end{tabular}

propinsi yang mengalami penurunan populasi yang paling tajam di banding populasi yang lain di Jawa yaitu $13,19 \%$ dari 32.857 .497 ekor pada tahun 2004 menjadi 28.520.480 ekor tahun 2005 (Tabel 1).

Sumber: Direktorat Jenderal Bina produksi Peternakan

Produksi daging ayam ras pedaging di Indonesia dari tahun 2001 sebesar 536.954 ton meningkat menjadi 883.370 ton pada tahun 2005 atau meningkat sebesar $16,13 \%$ per tahun. Perkembangan produksi daging ayam ras pedaging di beberapa propinsi di Pulau Jawa terutama di Jawa Barat juga mengalami peningkatan, sedangkan Jawa Timur pada tahun 2004 - 2005 mengalami penurunan ( Tabel 1).

Kasus flu burung yang merebak tahun 2003 ternyata tidak berpengaruh pada konsumsi daging 
ayam ras. Hal ini ditunjukkan dari data yang ada, konsumsi daging ayam ras di Jawa Timur terus meningkat dari tahun 2001 - 2004 yaitu sebesar $11,76 \%$ per tahun. Tingginya tingkat konsumsi tersebut masih belum dapat dicukupi oleh produksi daging ayam ras pedaging dari populasi yang ada di daerah tersebut. Untuk menutup kekurangan tersebut salah satu usaha yang dilakukan adalah melakukan impor dari daerah lain.

Ayam ras pedaging merupakan salah satu jenis komoditas ternak yang menghasilkan daging dan memiliki nilai ekonomi yang cukup potensial. Beternak ayam ras pedaging benarbenar memiliki keuntungan yang tidak dimiliki oleh ternak lainnya yaitu waktunya pendek, pertumbuhannya cepat juga menghasilkan kotoran yang mempunyai nilai dwiguna (Hartono, 1999).

Komoditas yang mempunyai daya saing adalah komoditas yang efisien dalam penggunaan sumberdaya domestik serta komoditas yang sesuai dengan keinginan dan kebutuhan konsumen. Oleh karena itu komoditas yang mempunyai keunggulan komparatif dan kompetitif adalah komoditas yang dapat bersaing di pasar global. Hal ini sesuai dengan yang dikemukakan oleh Darmaji (1998), bagi komoditas yang diperdagangkan secara internasional, yang sekaligus merupakan kriteria mendasar yang menentukan mampu tidaknya komoditas bersaing di pasar global. Jawa Timur merupakan salah satu propinsi yang dapat diandalkan dapat bersaing di pasar dunia dengan memiliki kekuatan potensial dari sumberdaya pertaniannya. Kondisi tropis, iklim dan cuaca yang dimiliki Jawa Timur sangat cocok mendukung pertumbuhan dan perkembangan pertanian. Selain sumberdaya yang dimiliki, potensi perdagangan hasil pertanian Jawa Timur cukup besar pula dibandingkan sektor yang lainnya (Akhdaryani, 2002).

Agribisnis ayam ras pedaging memiliki daya saing atau keunggulan komparatif dalam pengusahaannya. Pengusahaan ayam ras pedaging dengan sasaran pemenuhan kebutuhan domestik, secara ekonomis adalah efisien dalam pemanfaatan sumberdaya di dalam negeri. Di samping itu pada tingkat atau status ekonomi dan daya beli masyarakat saat ini produksi ayam ras pedaging telah mencapai swasembada, sehingga jenis usaha ini telah memberi sumbangan yang berarti terhadap pencapaian ketahanan pangan di dalam negeri (Siregar dan Rusastra, 2003).

Krisis ekonomi tahun 1998 turut berdampak negatif pada hampir $80 \%$ peternak unggas di Indonesia yang saat ini sedang berkembang pesat (Waluyo, 2005). Kebijakan pemerintah dengan mencanangkan hari kebangkitan peternak di Indonesia dapat meningkatkan harga 
jual produk unggas. Namun mewabahnya flu burung (AI) di Indonesia (bahkan di dunia) pada akhir tahun 2003 mengakibatkan turunnya harga produk unggas serta menimbulkan kerugian yang relatif besar bagi peternak yang terkena penyakit ini.

Usaha ternak ayam ras pedaging di

Kabupaten Lamongan 100\% peternak ikut pola kemitraan karena terbatasnya modal serta ipeternak bergabung dengan perusahaan $\mathrm{CV}$. Maria Bloiler. Keberadaan CV. Maria Bloiler bagi peternak di Kabupaten Lamongan mampu menggerakkan para peternak dalam melakukan kemitraan usaha mulai proses perencanaan sampai dengan pemasaran hasil produksi, dengan pembagian keuntungan yang memuaskan kedua belah pihak (kelompok ternak).
Pola kemitraan yang digunakan oleh peternak di Kabupaten Lamongan adalah pola kemitraan PIR (Perusahaan Inti Rakyat) pengunggasan, dimana peternak sebagai plasma hanya menyediakan tanah, kandang, peralatan, dan tenaga kerja, sedangkan perusahaan sebagai intinya menyediakan semua yang dibutuhkan peternak seperti DOC (Day Old Chick), pakan, obatobatan, dan lain-lain.

Pada tahun 2001 - 2005 populasi ayam ras pedaging di Kabupaten Lamongan terus mengalami kenaikan. Pada tahun yang sama produksi daging ayam ras pedaging juga mengalami peningkatan, namun pada tahun 2005 produksi daging ayam ras pedaging di Kabupaten Lamongan mengalami penurunan yang cukup drastis (Tabel 2).

Tabel 2. Populasi Ayam Ras Pedaging dan Produksi Daging Ayam Ras Pedaging di Kabupaten Lamongan Tahun 2001 - 2005

\begin{tabular}{|l|c|c|c|c|c|}
\hline & $\mathbf{2 0 0 1}$ & $\mathbf{2 0 0 2}$ & $\mathbf{2 0 0 3}$ & $\mathbf{2 0 0 4}$ & $\mathbf{2 0 0 5}$ \\
\hline $\begin{array}{l}\text { Populasi } \\
\text { (ekor) }\end{array}$ & 581.954 & 608.716 & 611.759 & 783.481 & 814.800 \\
\hline $\begin{array}{l}\text { Produksi } \\
(\mathrm{Kg})\end{array}$ & 1.680 .391 & 2.039 .597 & 2.859 .614 & 3.270 .255 & 2.077 .740 \\
\hline
\end{tabular}

Sumber: Dinas Peternakan Propinsi Jawa Timur

Kasus flu burung juga berdampak yang besar terhadap keadaan sosial dan ekonomi peternak unggas, khususnya peternak ayam ras yang ayamnya habis mati akibat flu burung atau terpaksa dimusnahkan oleh aparat. Secara sosial peternak merasa terisolasi, karena orang lain merasa takut dan hati-hati untuk berkunjung ke peternaknya. Secara ekonomi peternak mengalami kerugian, karena kehilangan ternaknya yang tidak sedikit sehingga pendapatan peternak juga mengalami penurunan.

METODE PENELLITIAN 
Responden dalam penelitian ini adalah peternak ayam pedaging yang ada di Kabupaten Lamongan Propinsi Jawa Timur. Pelaksanaan penelitian dari bulan April sampai Juli 2010. Jumlah peternak responden yang diambil dalam penelitian ini sebanyak 75 peternak dari sekitar 300 peternak yang diambil secara acak terstratifikasi dengan skala usaha 3000 - 8000 ekor per periode produksi. Skala usaha adalah jumlah kepemilikan ternak ayam pedaging (jumlah ayam yang dipelihara) oleh seorang peternak per satu angkatan pemeliharaan. Model usaha ternak ayam pedaging di Kabupaten Lamongan ini adalah secara kemitraan.

Data diperoleh secara langsung dari peternak dengan melakukan wawancara dan bantuan kuesioner. Data utama sebagai dasar analisis dalam penelitian ini adalah: (1) elemen-elemen biaya produksi meliputi listrik, perawatan, tenaga kerja, pakan, DOC, obat-obatan, dan vaksin; (2) penerimaan yang berasal dari penjualan ayam.

Analisis keunggulan komparatif agribisnis ayam ras pedaging digunakan rumus sebagai berikut:

$\mathrm{DRCR}=\overline{S E R}$

Dimana:

DRCR = rasio biaya sumberdaya domestic (\%)

$\mathrm{DRC}=$ biaya sumberdaya domestic yang digunakan $(\mathrm{Rp})$
SER = Shadow exchange rate (Rp/US\$)

kriteria penilaian adalah:

$\begin{aligned} & \text { DRCR } \\ & \text { agribisnis } \\ & \text { pedaging tidak } \\ & \text { ayam }\end{aligned} \begin{array}{r}\text { ras } \\ \text { efisien }\end{array}$
secara ekonomik atau tidak
mempunyai keunggulan
kompetitif.

DRCR < 1, berarti agribisnis ayam ras pedaging efisien dan secara ekonomi mempunyai keunggulan kompetitif.

DRCR = $1, \quad$ berarti agribisnis ayam ras pedaging dalam keseimbangan

Sedangkan analisis keunggulan komparatif agribisnis ayam ras pedaging menggunakan rumus sebagai berikut:

$\mathrm{PCR}=\frac{D R C}{N T R}$

Dimana:

$\mathrm{PCR}=$ rasio biaya sumberdaya domestic atau harga actual (\%)

$\mathrm{DRC}=$ biaya sumberdaya domestic berdasarkan harga aktual (Rp)

$\mathrm{NTR}=$ nilai tengah rupiah (Rp/US\$)

kriteria penilaian adalah:

PCR $>1$, berarti agribisnis ayam ras pedaging tidak efisien secara finansial atau tidak mempunyai keunggulan komparatif. 
PCR $<1$, berarti agribisnis ayam ras pedaging efisien dan secara finansial mempunyai keunggulan komparatif.

PCR $=1$, berarti agribisnis ayam ras pedaging dalam keseimbangan
Policy Analysis Matrix (PAM) digunakan untuk menganalisis dampak kebijakan harga maupun kebijakan investasi pertanian. Hasil analisis PAM dapat menunjukkan pengaruh individual maupun kolektif dari kebijakan harga dan kebijakan faktor domestik. Metode ini dapat di lihat pada tabel 3 di bawah ini:

Tabel 3. Policy Analysis Matrix (PAM)

\begin{tabular}{|l|c|c|c|c|}
\hline & \multirow{2}{*}{ Penerimaan } & \multicolumn{2}{|c|}{ Biaya } & \multirow{2}{*}{\begin{tabular}{l} 
pendapatan \\
\cline { 3 - 5 }
\end{tabular}} \\
\cline { 3 - 5 } & Input & Input domestic & $\mathrm{D}$ \\
\hline Harga pasar & $\mathrm{E}$ & $\mathrm{B}$ & $\mathrm{C}$ & $\mathrm{H}$ \\
\hline Harga social & $\mathrm{I}$ & $\mathrm{J}$ & $\mathrm{K}$ & $\mathrm{L}$ \\
\hline $\begin{array}{l}\text { Policy } \\
\text { transfer }\end{array}$ & & & & \\
\hline
\end{tabular}

Keterangan:

$\mathrm{A}=$ penerimaan individu, yaitu produksi dikalikan dengan harga pasar ( $\mathrm{Rp})$

$\mathrm{B}=$ input tradable dikalikan dengan harga pasar (Rp)

$\mathrm{C}=$ input faktor domestik dikalikan dengan harga pasar $(\mathrm{Rp})$

$\mathrm{D}=$ pendapatan individu, $(\mathrm{A}-(\mathrm{B}+\mathrm{C})) \ldots \ldots \ldots . .(\mathrm{Rp})$

$\mathrm{E}=$ Penerimaan sosial, yaitu produksi dikalikan dengan harga sosial (Rp)

$\mathrm{F}=$ input tradable dikalikan dengan sosial ( $\mathrm{Rp})$

$\mathrm{G}=$ input faktor domestik dikalikan dengan harga sosial (Rp)

$\mathrm{H}=$ pendapatan sosial, $(\mathrm{E}-(\mathrm{F}+\mathrm{G}))$

$\mathrm{I}=$ output transfer $(\mathrm{A}-\mathrm{E})$

$\mathrm{J}=$ input transfer $(\mathrm{B}-\mathrm{F})$

$\mathrm{K}=$ factor domestik transfer $(\mathrm{C}-\mathrm{G})$

$\mathrm{L}=$ Net policy transfer $(\mathrm{D}-\mathrm{H})$

HASIL DAN PEMBAHASAN Analisis Keunggulan Komparatif Usaha Agribisnis Ayam Ras Pedaging di Kabupaten Lamongan Jawa Timur

Keunggulan komparatif disini digunakan untuk menganalisis tingkat efisiensi ekonomi penggunaan sumberdaya domestik dari produk ayam ras pedaging dalam upaya menghemat/menambah devisa melalui pengurangan impor dan menambah pangsa pasar. Tingkat keunggulan komparatif ini 
ditunjukkan oleh nilai DRCR (domestic resource cost rasio), yaitu perbandingan antara faktor domestik dengan hasil pengurangan dari penerimaan dengan input tradable.
Hasil analisis keunggulan komparatif komoditas ayam ras pedaging bias di lihat pada tabel 4 di bawah ini:

Tabel 4. Hasil analisis DRCR komoditas ayam ras pedaging di Kabupaten Lamongan, sebelum dan sesudah adanya kasus flu burung per siklus

\begin{tabular}{|l|r|r|r|r|}
\hline \multirow{2}{*}{ Uraian } & \multicolumn{2}{|c|}{ Sebelum } & \multicolumn{2}{c|}{ Sesudah } \\
\cline { 2 - 5 } & Skala $\leq 5000$ & Skala $\geq 5000$ & Skala $\leq 5000$ & Skala $\geq 5000$ \\
\hline $\begin{array}{l}\text { Faktor } \\
\text { domestic (Rp) }\end{array}$ & $2.490 .588,49$ & $2.993 .884,50$ & $2.490 .588,49$ & $2.993 .884,50$ \\
\hline $\begin{array}{l}\text { Input tradable } \\
(\text { Rp) }\end{array}$ & $44.451 .037,03$ & $88.950 .952,37$ & $41.204 .648,14$ & $82.846 .666,67$ \\
\hline $\begin{array}{l}\text { Penerimaan } \\
(\text { Rp) }\end{array}$ & $48.204 .463,02$ & $94.140 .437,86$ & $44.351 .777,78$ & $87.335 .105,00$ \\
\hline DRCR (\%) & 0,66 & 0,57 & 0,79 & 0,67 \\
\hline
\end{tabular}

Sumber: Diolah dari data primer

Tabel 4 menunjukkan bahwa nilai DRCR $<1$ baik pada kondisi sebelum maupun sesudah adanya kasus flu burung. Usaha ternak ayam ras pedaging sebelum adanya kasus flu burung pada berbagai tingkat skala usaha memiliki tingkat keunggulan komparatif lebih tinggi, hal ini ditunjukkan oleh nilai DRCR sebesar $0,66 \%$ dan $0,57 \%$ lebih kecil daripada nilai DRCR sesudah adanya kasus flu burung yaitu sebesar $\quad 0,79 \%$ dan $\quad 0,67 \%$. Sedangkan jika dilihat dari skala usahanya, pada skala usaha $\geq 5000$ ekor mempunyai keunggulan komparatif lebih tinggi daripada skala usaha $\leq 5000$ ekor. Keunggulan komparatif yang dimiliki oleh Kabupaten Lamongan pada usaha ternak ayam ras pedaging diantaranya adalah rendahnya biaya input domestik seperti upah tenaga kerja dan sewa lahan.

Nilai DRCR sebesar 0,66\% yang berarti, setiap penggunaan biaya sebesar $66 \%$ akan memberikan keuntungan secara ekonomik sebesar $34 \%$ dari total biaya. Begitu juga dengan nilai DRCR sebesar $0,57 \%$ artinya setiap penggunaan biaya sebesar $57 \%$ akan memberikan keuntungan secara ekonomik sebesar $43 \%$ dari total biaya. Dengan demikian semakin kecil nilai DRCR maka keuntungan yang diperoleh juga semakin besar, begitu juga sebaliknya jika nilai DRCR semakin 
besar maka keuntungan yang

diperoleh akan semakin kecil.

\section{Analisis keunggulan kompetitif usaha agribisnis ayam ras pedaging di Kabupaten Lamongan Jawa Timur}

Keunggulan kompetitif ini digunakan untuk menganalisis tingkat efisiensi finansial. Tingkat keunggulan kompetitif ini ditunjukkan oleh nilai PCR (profit cost ratio), perbandingan antara faktor domestik dengan nilai pengurangan antara penerimaan dan input tradable. PCR memainkan fungsi yang sama seperti DRCR, hanya berbeda dalam dasar penilaian harga. PCR dinilai dalam harga privat (finansial). Hasil analisis keunggulan kompetitf komoditas ayam ras pedaging bisa dilihat pada tabel 5 di bawah ini:

Tabel 5. Hasil analisis PCR komoditas ayam ras pedaging di Kabupaten Lamongan, sebelum dan sesudah adanya kasus flu burung per siklus

\begin{tabular}{|l|r|r|r|r|}
\hline \multirow{2}{*}{ Uraian } & \multicolumn{2}{|c|}{ Sebelum } & \multicolumn{2}{c|}{ Sesudah } \\
\cline { 2 - 5 } & Skala $\leq 5000$ & Skala $\geq 5000$ & Skala $\leq 5000$ & Skala $\geq 5000$ \\
\hline $\begin{array}{l}\text { Faktor } \\
\text { domestic (Rp) }\end{array}$ & $2.393 .588,60$ & $2.898 .884,62$ & $2.393 .588,60$ & $2.898 .884,62$ \\
\hline $\begin{array}{l}\text { Input tradable } \\
(\mathrm{Rp})\end{array}$ & $45.612 .518,51$ & $91.252 .380,95$ & $39.545 .110,71$ & $78.778 .571,42$ \\
\hline $\begin{array}{l}\text { Penerimaan } \\
(\mathrm{Rp})\end{array}$ & $49.952 .111,15$ & $96.469 .378,43$ & $42.336 .700,00$ & $82.789 .216,43$ \\
\hline PCR (\%) & 0,55 & 0,56 & 0,85 & 0,72 \\
\hline
\end{tabular}

Sumber: Diolah dari data primer

Pada tabel 5 di atas, diketahui bahwa komoditas ayam ras pedaging di Kabupaten Lamongan baik sebelum maupun sesudah adanya kasus flu burung memiliki keunggulan kompetitif, hal ini ditunjukkan oleh nilai $\mathrm{PCR}<1$. Usaha ternak ayam ras pedaging sebelum dan sesudah adanya kasus flu burung pada berbagai skala usaha, memiliki tingkat keunggulan kompetitif lebih tinggi dengan melihat nilai PCR sebesar $0,55 \%$ dan $0,56 \%$ lebih kecil daripada PCR usaha ternak ayam ras pedaging sesudah adanya kasus flu burung pada berbagai skala usaha yang nilainya sebesar $0,85 \%$ dan $0,72 \%$.

Nilai PCR sebesar $0,55 \%$ yang berarti setiap penggunaan biaya sebesar $55 \%$ akan memberikan keuntungan secara finansial sebesar $45 \%$ dari total biaya. Begitu juga dengan nilai PCR sebesar 0,56\%, artinya setiap penggunaan biaya sebesar 56\% akan memberikan keuntungan secara finansial sebesar $44 \%$ dari total biaya. Dengan demikian semakin kecil nilai PCR 
maka keuntungan yang diperoleh semakin besar, begitu juga sebaliknya jika nilai PCR semakin besar maka keuntungan yang diperoleh akan semakin kecil.

Pada usaha ayam ras pedaging di Kabupaten Lamongan baik sebelum dan sesudah adanya kasus flu burung pada berbagai skala usaha memiliki niai $\mathrm{PCR}<\mathrm{DRCR}$ artinya tingkat keunggulan kompetitif yang dimiliki lebih tingg daripada kenggulan komparatif, sehingga keutungan finansial lebih besar daripada keuntugan ekonomik, dengan kata lain untuk menunjang keunggulan komparatif masih diperlukan kebijakan pemerintah.

Analisis dampak flu burung terhadap daya saing usaha agribisnis ayam ras pedaging

Adanya kasus flu burung pada peternakan di Indonesia menyebabkan pemerintah harus mengeluarkan beberapa kebijakan untuk menyelamatkan para peternak. Kebijakan pemerintah menimbulkan dampak terhadap kinerja agribisnis ayam ras pedaging, antara lain efisiensi/daya saingnya. Untuk mengetahui dampak yang terjadi dipergunakan Metode Matrix Analisa Kebijakan (PAM).
Matrix PAM ini disusun berdasarkan data biaya produksi usahaternak dan biaya tataniaga serta harga output berupa daging yang telah dipisahkan dalam komponen tradable dan domestic. Hasil analisis PAM pada usaha ternak ayam ras daging di Kabupaten Lamongan lampiran 1.

Ukuran dampak dan kebijakan pemerintah dalam matrix PAM adalah transfer output (OT), transfer input (IT), transfer factor (FT) dan transfer bersih (NT). Ukuran relatif ditunjukkan oleh analisis koefisien output nominal atau nominal protection coefficient on output (NPCO), koefisien proteksi input nominal atau nominal protection coefficient on input (NPCI), koefisien proteksi efektif atau effectif protection coefficient (EPC) dan koefisien profitabilitas atau profitability coefficient (PC).

Adapun indikator yang digunakan dalam analisis PAM disajikan pada tabel 6 berikut:

Table 6. Indikator analisis Policy Analysis Matrix (PAM) pada usahaternak ayam ras pedaging di Kabupaten Lamongan sebelum dan sesudah adanya kasus flu burung per siklus

\begin{tabular}{|l|l|l|l|l|l|}
\hline \multirow{2}{*}{ uraian } & iindikator & \multicolumn{2}{|c|}{ Sebelum } & \multicolumn{2}{|c|}{ sesudah } \\
\cline { 3 - 6 } & & Skala $\leq 5000$ & Skala $\geq 5000$ & $\begin{array}{l}\text { Skala } \\
5000\end{array}$ & Skala $\geq 5000$ \\
\hline $\begin{array}{l}\text { Pendapatan } \\
\text { individual } \\
(\mathrm{Rp})\end{array}$ & $\mathrm{A}-(\mathrm{B}+\mathrm{C})$ & $1.946 .004,25$ & $2.318 .110,86$ & $398.000,55$ & $\begin{array}{l}1.120 .760, \\
38\end{array}$ \\
\hline
\end{tabular}




\begin{tabular}{|l|l|r|r|r|l|}
\hline $\begin{array}{l}\text { Pendapatan } \\
\text { social (Rp) }\end{array}$ & $\mathrm{E}-(\mathrm{F}+\mathrm{G})$ & $1.359 .837,61$ & $1.492 .981,81$ & $753.541,31$ & $791.934,67$ \\
\hline DRCR (\%) & $\mathrm{G} /(\mathrm{E}-\mathrm{F})$ & 0,66 & 0,57 & 0,79 & 0,67 \\
\hline PCR (\%) & $\mathrm{C} /(\mathrm{A}-\mathrm{B})$ & 0,55 & 0,56 & 0,85 & 0,72 \\
\hline NPCO (\%) & $\mathrm{A} / \mathrm{E}$ & 1,03 & 1,02 & 0,95 & 0,94 \\
\hline NPCI (\%) & $\mathrm{B} / \mathrm{F}$ & 1,02 & 1,02 & 0,95 & 0,95 \\
\hline EPC (\%) & (A - B)/(E- & 1,15 & 1,00 & 0,88 & 0,89 \\
& $\mathrm{~F})$ & 1,43 & 1,55 & 0,53 & 1,41 \\
\hline PC (\%) & $\mathrm{D} / \mathrm{H}$ & $1.747 .648,13$ & $2.328 .938,57$ & - & $-4.536 .888,57$ \\
\hline OT (\%) & $\mathrm{A}-\mathrm{E}$ & & & 2.015 .077$, & \\
& & $1.161 .481,48$ & $2.301 .428,58$ & - & $-4.068 .095,24$ \\
& & & & 1.659 .537$, & \\
\hline IT (\%) & $\mathrm{B}-\mathrm{F}$ & & & -43 & $328.825,71$ \\
& & $586.166,64$ & $825.129,05$ & $355.540,76$ & \\
\hline NT (\%) & $\mathrm{D}-\mathrm{H}$ & & &
\end{tabular}

Sumber: diolah dari data primer

Kebijakan pemerintah terhadap komoditas ayam ras pedaging dapat berupa kebijakan terhadap output maupun input. Nilai koefisien output nominal (NPCO) sebesar $1,03 \%$ pada skala usaha $\leq 5000$ ekor dan $1,02 \%$ pada skala $\geq 5000$ ekor, artinya pemerintah melakukan transfer output kepada peternak sebesar Rp.1.747.648,13/siklus dan Rp.2.328.938,57 per siklus pada usaha ternak ayam ras pedaging sebelum adanya kasus flu burung. Sedangkan sesudah adanya kasus flu burung nilai NPCO sebesar $0,95 \%$ pada skala usaha $\leq 5000$ ekor dan $0,94 \%$ pada skala usaha $\geq 5000$ ekor, artinya pemerintah melakukan transfer output kepada peternak sebesar Rp. 2.015.077,78 (minus)/siklus dan Rp. 4.536.888,57(minus)/ siklus pada usaha ternak ayam ras pedaging.

Nilai koefisien proteksi input nominal (NPCI) usaha ternak ayam ras pedaging sebelum adanya kasus flu burung pada berbagai skala usaha bernilai $>1$, hal ini menunjukkan bahwa pemerintah melakukan proteksi terhadap produsen input tradable. Setelah adanya kasus flu burung nilai NPCI $<1$. Hal ini berarti bahwa pada daerah ini tidak terdapat proteksi pada produsen input tradable.

Nilai EPC pada usaha ternak ayam ras pedaging baik sebelum maupun sesudah adanaya kasus flu burung pada berbagai skala usaha memiliki nilai $>1$, artinya bahwa secara umum peternak diuntungkan dengan adanya intervensi pemerintah. Adapun nilai koefisiensi keuntungan (PC) usaha ternak ayam ras pedaging sebelum dan sesudah adanya kasus flu burung pada berbagai skala usaha bernilai $>1$, 
menunjukkan bahwa dengan adanya intervensi pemerintah keuntungan individual yang diterima peternak lebih besar dari keuntungan social yang diterima konsumen. Rasio subsidi bagi produsen (SRP) mempunyai nilai sama dengan atau mendekati nol, ini menunjukkan kebijakan pemerintah tidak berdampak secara langsung pada biaya usaha ternak ayam ras pedaging.

Dampak flu burung dapat dilihat dari perubahan harga input tradable, harga daging ayam ras pedaging dan upah tenaga kerja terhadap daya saing usaha agribisnis ayam ras pedaging. Perubahan input tradable berhubungan negative dengan keunggulan komparatif dan keunnggulan kompetitif, artinya semakin besar persentase kenaikan maka semakin rendah keunggulan komparatif dan keunggulan kompetitif usaha ternak ayam ras pedaging. Sebaliknya semakin besar penurunannya maka semakin tinggi keunggulan komparatif dan keunggulan kompetitif usaha ternak ayam ras pedaging. Hal tersebut dengan asumsi jika satu variabel berubah, maka variabel lainnya bersifat tetap.

Perubahan harga sosial ayam ras pedaging berhubungan positif dengan keunggulan komparatif, sedangkan harga actual daging ayam ras pedaging berhubungan positif dengan keunggulan kompetitif. Semakin besar persentase kenaikannya maka semakin tinggi keunggulan komparatif dan keunggulan kompetitif usaha ternak ayam ras pedaging dan sebaliknya semakin besar persentase penurunannya maka semakin rrendah keunggulan komparatif dan keunggulan kompetitif.

Perubahan harga, input tradable, daging ayam ras pedaging dan upah tenaga kerja dengan aumsi terjadi peningkatan secara bersama-sama berhubungan positif dengan keunggulan komparatif dan keunggulan kompetitif, artinya semakin besar persentase kenaikkannya maka semakin tinggi keunggulan komparatif dan keunggulan kompetitif dan sebaliknya semakin besar persentase penurunannya maka semakin rendah keunggulan komparatif dan keunggulan kompetitif usaha ternak ayam ras pedaging. Hasil diatas menunjukkan bahwa dengan adanya kasus flu burung di Kabupaten Lamongan masih berdampak positif terhadap daya saing usaha agribisnis ayam ras pedaging.

\section{Kesimpulan}

\section{KESIMPULAN DAN SARAN}

1. Usaha ternak ayam ras pedaging di Kabupaten Lamongan secara keseluruhan memiliki keunggulan komparatif dan keunggulan kompetitif, hal tersebut ditunjukkan oleh nilai DRCR $<1$ dan $\quad \mathrm{PCR}<1$.

2.Perubahan harga daging ayam ras pedaging berhubungan positif dengan daya saing komoditas ayam ras pedaging, sedangkan perubahan input tradable dan tenaga kerja berhubungan negative dengan daya saing komoditas ayam ras pedaging. Namun, jika terjadi perubahan secara bersama-sama, 
maka berhubungan positif dengan daya saing usaha agribisnis ayam ras pedaging. Hal tersebut dengan asumsi ceteris paribus

\section{Saran}

Usaha agribisnis ayam ras pedaging di Kabupaten Lamongan perlu meningkatkan kinerja usahanya. Salah satu caranya adalah dengan melakukan manajemen pemeliharaan yang tepat dan pemberian pakan yang berkualitas sesuai dengan kebutuhan pakan, karena hal tersebut merupakan salah satu factor terpenting bagi pencapaian kinerja yang baik. Dengan adanya kinerja yang baik secara otomatis akan memberikan keuntungan terhadap peternak melalui peningkatan pendapatannya yang sekaligus akan berpengaruh pada keunggulan komparatif dan kompetitif.

\section{DAFTAR PUSTAKA}

Abidin. 2002. Meningkatkan Produktifitas Ayam Ras Pedaging. Cetakan Pertama. Jakarta: Agromedia Pustaka

Akhdaryani, D. 2002. Analisis Keunggulan Komparatif Komoditas Andalan Utama Sektor Pertanian Jawa Timur Menjelang Perdagangan Global. Publikasi Ilmiah. Malang: Universitas Brawijaya.

Direktorat Jenderal Peternakan. 2005. Infoeksekutif. www.deptan.go.id/infoeksekutif/nak/2005.

Hartono, F. 1999. Beternak Ayam Pedaging Super. Pekalongan: Penerbit CV.Gunung Mas.

Siregar, M dan I Wayan Rusastra. 2003. Kebijakan Tarif Impor Paha Ayam dalam Melindungi Industri Perunggasan Nasional. Jurnal SOCA. Volume 3. Denpasar: Fakultas Pertanian Universitas Udayana.

Syafaat, N., Supena P., Sudi M., dan Suryadi. 2004. Kinerja Nilai Tambah dan Produksi sector Pertanian, 2000 - 2003. Analisis Kebijakan Pertanian. Nomor 1, Volume 2, Maret 2004. Bogor: Institut Pertanian Bogor. 


















































































































































































































































































































































